Agata NodŻaK ${ }^{1}$

\title{
Wykorzystanie nowoczesnych technologii w kontekście rozwoju społeczeństwa obywatelskiego w Polsce
}

\section{Wprowadzenie}

W przeciągu ostatnich kilkudziesięciu lat można zaobserwować stale postępujący intensywny postęp cywilizacyjny, dokonujący się m.in. poprzez rozwój technologii informatycznych i telekomunikacyjnych. Rozwój ten towarzyszy przemianom gospodarczym, a nawet politycznym czy społecznym. Według poglądów spotykanych w piśmiennictwie jednym z przejawów przemian społecznych na skutek rozwoju i popularyzacji nowoczesnych technologii jest wykształcenie się społeczeństwa informacyjnego, społeczeństwa cyfrowego czy też nawet cyberspołeczeństwa ${ }^{2}$. Abstrahując od stosowanej terminologii, jedynie nadmienię w tym miejscu, iż w literaturze ciągle pojawiają się próby zdefiniowania tego pojęcia, jak i samego zjawiska, co nie jest prostym zadaniem. Natomiast najczęściej zakłada się, że „społeczeństwo informacyjne to takie, w którym każdy (...) posiada dostęp do technologii informacyjnych i komunikacyjnych (tj.: komputerów, Internetu i innych sieci, telefonów, smartfonów, tabletów, serwerów, terminali, smart TV), ma umiejętności, świadomość i możliwości wykorzystania [tych technologii - przypis A.N.] do sprawnego pozyskiwania wiarygodnej informacji po to, aby jak najlepiej zrealizować swoje cele”3.

Intensyfikacja rozwoju nowoczesnych technologii i towarzyszące im przemiany natury społecznej nasiliły się w szczególności od chwili pojawienia się Internetu ${ }^{4}$. Dzięki rozwojowi i popularyzacji nowych mediów ła-

1 Dr Agata Nodżak, Instytut Prawa, Administracji i Ekonomii, Uniwersytet Pedagogiczny im. Komisji Edukacji Narodowej w Krakowie.

$2 \mathrm{~W}$ stosunku do tak określanego społeczeństwa można spotkać zastosowanie również innych terminów, jak np. społeczeństwo komputerowe, telematyczne czy info-biotechnologiczne. Zob. na ten temat: L.W. Zacher, Etykietowanie przyszłych społeczeństw - kryteria, określenia, ewaluacje [w:] U progu wielkiej zmiany? Media w kulturze XXI wieku, M. Sokołowski (red.), Olsztyn 2005.

3 R. Żelazny, Raport Obserwatorium ITC. Społeczeństwo informacyjne, Gliwice 2013, s. 9.

4 Zob. W.I. Bennett, R.M. Entman, Mediated politics: communication on the future of democracy, Cambrigde-New York 2005, s. 1-29. 
twiejszy i szybszy stał się dostęp do informacji i wiedzy, co moim zdaniem miało istotny wpływ na wzrost społecznej świadomości zarówno jednostek, jak i tworzonych przez nie grup, społeczności, do zmiany ich oczekiwań względem państwa i jego władz oraz podejmowanych przez nie procesów decyzyjnych, do ukształtowania się nowego spojrzenia na sposób i formę uczestnictwa jednostek w zajmowaniu się sprawami publicznymi. Podobnego zdania jest A. Hess, która twierdzi, iż „rozwój i popularyzacja nowych mediów (...) zbiegły się w czasie z nasileniem krytyki dotyczącej społecznych funkcji tradycyjnych środków masowego komunikowania. Do czasu nastania »ery Internetu« sfera publiczna w mediach była limitowana względami ekonomicznymi (druk, papier, urządzenia poligraficzne, nadawcze, itd.) bądź politycznymi (koncesje dla nadawców, cenzura). Biorąc pod uwagę nieznaczne koszty związane z dostępem do Internetu i zakładając brak ograniczeń natury politycznej w demokracjach, warunki wyjściowe dla tworzenia się społeczeństwa obywatelskiego i rozwoju sfery publicznej stały się sprzyjające"s. Nowoczesne technologie zatem nie tylko mogą sprzyjać realizacji zainteresowania obywatelskiego sprawami publicznymi w dotychczasowych formach, ale - jak podnosi się w literaturze, jak i praktyce, również wskazywać na konieczność zmiany dotychczasowego podejścia do partycypacji obywatelskiej. Pojawiają się w związku z tym w temacie poszczególnych form partycypacji obywatelskiej poglądy o dokonaniu swego rodzaju rewizji dotychczasowych rozwiązań i uzupełnienia ich o takie formy w toczących się procesach decyzyjnych, które będą korzystać również z nowoczesnych technik, narzędzi informatycznych i komunikacyjnych.

W literaturze można spotkać opracowania, których autorzy wskazują na szereg korzyści związanych z wykorzystaniem w procesie partycypacji obywatelskiej technologii informatycznych i telekomunikacyjnych, jak choćby podniesienie efektywności procesów decyzyjnych oraz jakości podejmowanych decyzji, ograniczenie konfliktów w społecznościach, wzrost wiarygodności i umocnienie wizerunku władz i jej administracji, a co najważniejsze- zwiększenie motywacji, zaangażowania poszczególnych jednostek w sprawy publiczne ${ }^{6}$. Przyjmując, że społeczeństwo obywatelskie to pewna perspektywa- postulat określający pewne pożądane modele partycypacji, aktywizacji, świadomości jednostek w życiu społecznym, jak iw kształ-

5 A. Hess, Społeczni uczestnicy medialnego dyskursu politycznego w Polsce. Mediatyzacja i strategie komunikacyjne organizacji pozarządowych, Kraków 2013, s. 41-42.

6 Zob. A. Tarasewicz, E-demokracja, czyli nowe technologie w polityce, http://educover.pl/czasopismo/e-demokracja-nowe-technologie-polityce/2/ (dostęp: 28.01.2017); Komunikacja i partycypacja społeczna. Nowoczesna Gmina - jak wykorzystać komunikację i partycypację społeczna jako skuteczne narzędzia zarzadzania jednostka samorzadowa, http://www.cds.krakow.pl/komunikacja_i_partycypacja_spoleczna,125.html (dostęp: 28.01.2017). Również na ten temat: M. Marczewska-Rytko, Demokracja elektroniczna jako próba urzeczywistnienia idei greckiej agory [w:] Spoteczeństwo informacyjne: wizja czy rzeczywistość?, t. 2, L.H. Haber (red.), Kraków 2004. 
towaniu struktur państwowych, zwolennicy nowoczesnych technologii uważają, że ich wykorzystanie może sprzyjać rozwojowi tak rozumianego społeczeństwa. Zastosowanie technologii może bowiem zoptymalizować warunki dla faktycznej realizacji partycypacji obywatelskiej, realizowanej dotychczas w konwencjonalny sposób, ułatwić korzystanie z poszczególnych jej form, a w rezultacie przyczynić się do wzrostu zainteresowania sprawami publicznymi ze strony obywateli. Mając to wszystko na uwadze, trudno jest zaakceptować poglądy, wedle których nowoczesne technologie doprowadzić mogą do wyparcia czy nawet zastąpienia tradycyjnych sposobów obywatelskiego uczestnictwa w życiu publicznym. Wskazują zresztą na to doświadczenia państw, które od kilkunastu lat sukcesywnie wdrażają i usiłują - czasami bez większych sukcesów - spopularyzować wśród swoich obywateli rozwiązania informatyczne i telekomunikacyjne przy realizacji poszczególnych form partycypacji.

W tym momencie bardziej zasadne jest stanowisko, według którego formy uczestnictwa korzystające z rozwiązań nowych technologii informatycznych w procesach demokratycznych należy potraktować raczej jako kolejną, dodatkową możliwość udziału, ułatwiającą partycypację tym, którzy dotąd $\mathrm{z}$ różnych przyczyn $\mathrm{w}$ nich nie uczestniczyli ${ }^{7}$, czy też zachętę do aktywnego uczestnictwa w sprawach publicznych, bowiem jak wskazują kolejne wybory czy referenda w Polsce czy też w innych państwach, tendencją jest raczej zjawisko malejącego zainteresowania sprawami publicznymi wśród poszczególnych społeczności i ich członków. Oczywiście przyczyn tego stanu rzeczy może być wiele, np. sceptyczna postawa i zniechęcenie elektoratu w stosunku do dotychczasowych ugrupowań politycznych czy też niewłaściwie prowadzona (a nawet nie prowadzona) przez władze polityka informacyjna.

Biorąc to wszystko pod uwagę, chcę zaprezentować najistotniejsze zagadnienia związane z wykorzystaniem nowoczesnych rozwiązań technologicznych w Polsce w przypadku najpopularniejszych form partycypacji obywatelskiej, takich jak głosowanie, konsultacje społeczne czy pozyskiwanie informacji publicznej. W szczególności chodzi o wyjaśnienie, czy wdrażanie technologii informatycznych i telekomunikacyjnych w celu ułatwienia korzystania z poszczególnych form partycypacji, głównie zaś pod auspicjami władz i jej administracji, może zachęcić współczesne społeczeństwo i jego członków do większego zaangażowania w sprawy publiczne i zażegnać tym samym kryzysu demokracji, a także ustalenie, czy i jaki wpływ te przedsięwzięcia mogą mieć na rozwój społeczeństwa obywatelskiego.

7 M. Musiał-Karg, Demokracja bezpośrednia w Szwajcarii. Wykorzystanie ICT w procedurach głosowania [w:] Demokracja bezpośrednia. Wymiar globalny i lokalny, M. Marczewska-Rytko, A.K. Piasecki (red.), Lublin 2010, s. 57. 


\section{Wykorzystanie nowoczesnych technologii w tradycyjnych formach partycypacji obywatelskiej - doświadczenia polskie i wybranych państw demokratycznych}

Rozwój technologii informatycznych wpłynął nie tylko na wiele dziedzin życia codziennego, prowadząc do jego przeobrażeń i wykształcenia się nowych zjawisk społecznych, ale ich oddziaływanie można również zaobserwować w procesach demokratycznych, w szczególności w odniesieniu do poszczególnych tradycyjnych form uczestnictwa obywateli w tych procesach.

Biorąc pod uwagę przedsięwzięcia zastosowania technologii $\mathrm{w}$ procesach demokratycznych w poszczególnych państwach demokratycznych, można zauważyć, iż w pierwszej kolejności wykorzystano je w procesie głosowania, po to aby usprawnić przebieg wyborów czy referendum.

W tym miejscu warto nadmienić, iż formy partycypacji obywatelskiej nie stanowią współcześnie zamkniętego katalogu. W systemach prawnych poszczególnych państw tylko niektóre z tych form zostały dokładnie unormowane w przepisach prawa (przede wszystkim wybory, referendum, obywatelskie prawo inicjatywy ustawodawczej, prawo do informacji publicznej), natomiast o innych formach prawodawca jedynie wspomina, nie dokonując ich wyczerpującej regulacji prawnej(np. o konsultacjach społecznych). Są i takie formy partycypacji, które pozostają niejako poza wyraźną regulacją systemu prawnego, np. obywatelskie prawo inicjatywy uchwałodawczej (chociaż w odniesieniu do tego ostatniego orzecznictwo sądowe i coraz częściej doktryna doszukuje się podstaw prawnych w Konstytucji, aktach prawa międzynarodowego itd.) ${ }^{8}$.

W świetle tej dygresji można pokusić się o stwierdzenie, że tak, jak różny jest stopień zainteresowania poszczególnymi formami partycypacji ze strony prawodawcy, tak samo w różnym stopniu władze publiczne widzą potrzebę czy możliwość wykorzystania rozwiązań bazujących na nowoczesnych technologiach. Doświadczenia poszczególnych państw w tym zakresie wskazują na konieczność przyjęcia indywidualnego podejścia w procesie informatyzacji do poszczególnych form partycypacji obywatelskiej. Stosowanie bowiem tych rozwiązań w przypadku poszczególnych form obywatelskiego uczestnictwa wiąże się ze zróżnicowanymi problemami, w szczególności związanymi z zagrożeniami dla szeroko pojętego porządku prawnego.

8 Zob. na ten temat: A. Nodżak, Obywatelskie prawo inicjatywy uchwałodawczej [w:] Legislacja czasu przemian, przemiany w legislacji. Ksiega jubileuszowa na XX-lecie Polskiego Towarzystwa Legislacji, M. Kłodawski, A. Witorska, M. Lachowski (red.), Warszawa 2016. 


\subsection{E-voting}

Elektroniczne głosowanie polega najczęściej na użyciu w procesie wyborczym specjalnych urządzeń elektronicznych zainstalowanych w lokalach wyborczych, na oddaniu głosu w specjalnych kioskach internetowych umieszczonych $\mathrm{w}$ różnych miejscach publicznych albo nawet przy użyciu telefonu komórkowego lub komputera podłączonego do Internetu. W przypadku tej formy partycypacji obywatelskiej nowoczesne technologie mogą znaleźć zastosowanie nie tylko $\mathrm{w}$ samym procesie oddawania głosów, ale również w przypadku poszczególnych czynności związanych z organizacją procesu wyborczego, np. do przyjmowania i zliczania głosów czy wizualizacji wyników wyborów9 . W przypadku zastosowania tych rozwiązań stopień wspomagania procesu wyborczego może być zróżnicowany - od stosowania rozwiązań informatycznych wyłącznie na potrzeby organów organizujących wybory, po rozwiązania, które pozwalają wyborcom na oddawanie głosów w lokalach wyborczych na specjalnie do tego przygotowanych urządzeniach. W takiej sytuacji zwykle wszystkie urządzenia znajdujące się w lokalach wyborczych tworzą swego rodzaju zamkniętą sieć, zarządzaną i kontrolowaną przez organy władzy publicznej i jej administrację. Innym rodzajem rozwiązania jest głosowanie przez Internet lub za pośrednictwem innych narzędzi telekomunikacyjnych. Zazwyczaj polega ono na tym, że głosy mogą być oddawane zdalnie z dowolnej lokalizacji i z dowolnego komputera posiadającego podłączenie do Internetu. Natomiast przyjęcia i zliczania oddanych w ten sposób głosów dokonuje centralny komputerowy system wyborczy. „Organizatorzy wyborów ustalają (...) tylko standardy oprogramowania, nie mają jednak wpływu na rodzaj infrastruktury w miejscach oddawania głosu i sposób jej skonfigurowania" ${ }^{10}$.

Spoglądając na genezę informatyzacji tej formy partycypacji obywatelskiej, można stwierdzić, że jej początki w poszczególnych państwach da się zaobserwować na przełomie XX i XXI w. Warto tutaj wymienić przedsięwzięcia wdrożenia rozwiązań informatycznych w USA, Belgii, Estonii, Brazylii czy Szwajcarii ${ }^{11}$. Jednakże „pełne zastosowanie evotingu odnajdziemy tylko w niektórych państwach. Współistnienie wielu różnych rozwiązań w prawodawstwie poszczególnych krajów powoduje, że tworzy się

9 Zob. na ten temat m.in. S. Koczubiej, E-głosowanie jako element demokracji w spoteczeństwie informacyjnym, „Problemy Humanistyki” 2003/2004, nr 8/9, s. 261-273.

10 M. Sztelmach, Wybory przez Internet - szansa czy zagrożenie?, http://www.psl. garwolin.pl/index.php/e-wybory-szansa-czy-zagroenie (dostęp: 2.02.2017).

11 Zob. na ten temat m.in. M. Czakowski, Evotingna przykładzie Estonii i Brazylii, „Studia BAS” 2011, nr 3 (27), s. 121-136; I. Wróbel, Szwajcarskie doświadczenia w głosowaniu przez Internet na przykładzie kantonu Zurych - wnioski dla Polski, e-Biuletyn Centrum Badań Problemów Prawnych i Ekonomicznych Komunikacji Elektronicznej 2008, nr 3, http://www.bibliotekacyfrowa.pl/dlibra/docmetadata $\mathrm{id}=34345 \&$ from $=\&$ dirids $=1 \&$ ver $\_\mathrm{id}=\& \mathrm{lp}=1 \& \mathrm{QI}=3 \mathrm{D} 5 \mathrm{E} 0 \mathrm{~A} 7 \mathrm{FE} 21 \mathrm{CDCC}$ -B96474A99A7AFE220-2 (dostęp: 2.02.2017). 
pewne rozwiązania indywidualne, najlepsze $z$ nich stają się wzorem i bywają w mniejszym bądź większym stopniu wykorzystywane przez innych. Czasem jednak zróżnicowanie rozwiązań jest na tyle duże i dostosowane do systemu prawnego konkretnego kraju, że pozostaje osobliwością regionalną" ${ }^{2}$. Jak się bowiem okazuje, o odmienności rozwiązań w poszczególnych państwach decyduje szereg uwarunkowań, jak choćby położenie geograficznie, powierzchnia terytorium danego państwa, liczba ludności czy zaszłości natury historycznej ${ }^{13}$. Tymczasem doświadczenia w zakresie e-votingu poszczególnych państw wskazują na to, iż jednym z najczęstszych i zarazem najistotniejszych problemów związanych z zastosowaniem nowoczesnych technologii w procesie wyborczym jest jednoznaczne, nie budzące wątpliwości i zagrożeń sfałszowania potwierdzenie tożsamości głosującego. Wspomniany problem jest rozwiązywany w różnorodny sposób, przy czym do najczęściej stosowanych należy potwierdzenie tożsamości przy pomocy podpisu elektronicznego lub przy wykorzystaniu elektronicznego dowodu osobistego ${ }^{14}$. Pierwszy sposób weryfikacji tożsamości głosującego może być w praktyce bardziej problematyczny, choćby ze względu na wysokie koszty, występujące głównie po stronie wyborcy, i trudności natury technicznej związane $\mathrm{z}$ wdrożeniem podpisu elektronicznego. Jest to rozwiązanie bardziej kosztowne przede wszystkim dla samego wyborcy, zatem trudno sobie wyobrazić, że będzie ono motywować obywateli do aktywnego udziału w procesie wyborczym i wpływać na wzrost frekwencji w wyborach. Mniejsze obawy budzi natomiast weryfikacja wyborcy przy pomocy elektronicznego dowodu osobistego, m.in. ze względu na to, że wydanie takiego dowodu i korzystanie $\mathrm{z}$ niego ma bardziej pragmatyczny charakter, istnieje bowiem możliwość jego wykorzystania do różnych celów, nie tylko w celu potwierdzenia tożsamości w wyborach.

Przy okazji warto zwrócić uwagę jeszcze na jeden fundamentalny dla większości wyborów warunek, który może nie zostać spełniony w razie zastosowania analizowanych rozwiązań. Chodzi tu o wymóg bezpośredniości i tajności, czyli de facto anonimowości głosowania. Powstaje bowiem pytanie, w jaki sposób zapewnić anonimowość wyborcy, którego tożsamość jest cyfrowo weryfikowana i w pewnym sensie taki sposób weryfikacji wiąże konkretnego wyborcę z oddanym głosem? Oczywiście, jak wskazują doświadczenia poszczególnych państw, technicznie jest możliwe zapewnienie wspomnianej anonimowości, np. w Estonii w ramach wdrożonego systemu głosowania przez Internet użyto specjalnych rozwiązań, centralnie zarządzanych, anonimizujących przesyłane głosy ${ }^{15}$. Można zatem potraktować

12 Ibidem, s. 122.

13 Ibidem.

14 Te sposoby weryfikacji wyborcy były stosowane podczas kolejnych wyborów w Estonii.

15 M. Kowalski, Głosowanie przez internet - dlaczego jeszcze nie w Polsce? Korzyści i zagrożenia związane $z$ wyborami elektronicznymi, http://softonet.pl/publi- 
to rozwiązanie jako gwarant anonimowości wyborcy, jednakże z drugiej strony powstaje nieodparte wrażenie utraty kontroli przez obywatela nad swoim głosem. Powoduje to również wzrost kosztów związanych z zastosowaniem odpowiednich technologii wyłącznie na potrzeby zapewnienia tajności głosowania.

Czy wdrożenie elektronicznego głosowania w opisany wyżej sposób jest możliwe w Polsce? Jak pokazują dotychczasowe doświadczenia, proces informatyzacji wyborów w Polsce przebiega stopniowo. Obecnie nie ma prawnie przewidzianych możliwości oddania głosu drogą elektroniczną, natomiast $\mathrm{w}$ samym procesie wyborczym od dłuższego czasu stosuje się nowoczesne technologie na potrzeby przeprowadzenia poszczególnych czynności związanych z przebiegiem wyborów ${ }^{16}$.

Wdrożenie technologii informatycznych i telekomunikacyjnych w procesach wyborczych w Polsce znajduje się dopiero na początku niełatwej drogi. Obecnie technologiczną innowacją, zastosowaną podczas powszechnych głosowań, jest elektroniczne przesyłanie wyników z obwodowych komisji wyborczych do centrali. Zgodnie z art. 230 ust. 6 ustawy z dnia 5 stycznia 2011 r. - Kodeks wyborczy ${ }^{17}$ przewodniczący okręgowej komisji wyborczej przekazuje niezwłocznie dane z protokołu dotyczące liczby głosów ważnych i głosów ważnych oddanych na każdą listę kandydatów oraz liczbę głosów ważnych oddanych na poszczególnych kandydatów z każdej z tych list do Państwowej Komisji Wyborczej, w sposób przez nią ustalony, za pośrednictwem sieci elektronicznego przesyłania danych. Następnie zebrane wyniki muszą być dodatkowo potwierdzone przez członków komisji. Obowiązujące przepisy prawa wskazują zatem na to, że wykorzystanie technologii informatycznych w Polsce w odniesieniu do wyborów ma, jak na razie, jedynie charakter subsydiarny i fragmentaryczny. Zastosowanie rozwiązań informatycznych służy m.in. prowadzeniu spisu wyborców ${ }^{18}$ czy też wspieraniu prac Państwowej Komisji Wyborczej. Kodeks wyborczy przewiduje zatem zastosowanie nowoczesnych technologii informatycznych i telekomunikacyjnych m.in. w takich kwestiach jak:

kacje/poradniki/Glosowanie.przez.internet-dlaczego.jeszcze.nie.w.Polsce.Korzysci.i.zagrozenia.zwiazane.z.wyborami.elektronicznymi,1383 (dostęp: 2.02.2017).

16 Zastanowienia wymaga natomiast pomysł wprowadzenia elektronicznego głosowania $\mathrm{w}$ Polsce $\mathrm{w}$ postaci programów pilotażowych (np. w referendum lokalnym w poszczególnych gminach) na wzór tego, co miało miejsce w innych państwach, jak choćby np. w Szwajcarii. Programy pilotażowe najpierw przeprowadzono w takich kantonach jak Genewa, Neuenburg czy Zurych. Przewidywały one m.in. możliwość zagłosowania drogą internetową, jak również poprzez wykorzystanie telefonii komórkowej (wysyłanie SMS).

17 Tekst jedn.: Dz. U. z 2017 r. poz. 15 ze zm.

18 Paragraf 4 rozporządzenia Ministra Spraw Wewnętrznych i Administracji z dnia 29 grudnia 2014 r. w sprawie spisu wyborców (Dz. U. z 2015 r. poz. 5). 
1) zgłoszenie w formie elektronicznej przez wyborcę, zmieniającego miejsce pobytu przed dniem wyborów, wniosku o wydanie zaświadczenia o prawie do głosowania w miejscu pobytu w dniu wyborów;

2) przekazywanie $w$ formie elektronicznej przez pracowników urzędu gminy informacji dotyczących organizacji wyborów wyborcy niepełnosprawnemu;

3) zgłoszenie w formie elektronicznej zamiaru głosowania korespondencyjnego;

4) możliwość wykorzystania techniki elektronicznej do zapewnienia obsługi i techniczno-materialnych warunków pracy obwodowych i terytorialnych komisji wyborczych;

5) przekazywanie przez przewodniczących okręgowych komisji wyborczych danych z protokołu wyborów w okręgu wyborczym do Państwowej Komisji Wyborczej;

6) możliwość wykorzystania techniki elektronicznej przy ustalaniu wyników głosowania, sporządzaniu protokołów przez obwodowe, terytorialne, rejonowe i okręgowe komisje wyborcze oraz Państwową Komisję Wyborczą przy sprawdzaniu pod względem zgodności arytmetycznej poprawności ustalenia wyników głosowania w obwodzie, ustalaniu wyników wyborów oraz przekazywaniu danych z protokołów;

7) publikowanie przez Państwową Komisję Wyborczą w formie dokumentu elektronicznego opracowań statystycznych zawierających szczegółowe informacje o wynikach głosowania i wyborów oraz udostępnianie w ten sposób wyników głosowania i wyników wyborów.

Biorąc pod uwagę przepisy Kodeksu wyborczego co do możności zastosowania technologii informatycznych, można stwierdzić, iż nadal w Polsce w przypadku organizacji form partycypacji obywatelskiej opierających się na głosowaniu podstawę stanowią karty do głosowania i protokoły, a rozwiązania informatyczne mają charakter uzupełniający, pomocniczy. Potwierdzenie tego można znaleźć w poglądach prezentowanych w piśmiennictwie. Przykładowo sędzia PKW W. Kozielewicz przy okazji wyborów prezydenckich w 2015 r., wyraźnie zaznaczył, iż „w polskich warunkach nie ma i długo nie będzie mechanizmu, który zastępowałby liczenie głosów przez człowieka. W naszym systemie prawnym każda karta do głosowania musi być przedmiotem oglądu odpowiedniej komisji wyborczej (...). Dopiero sprawdzony przez komisję głos może być zapisany w protokole z głosowania. W Polsce nie ma i długo nie będzie elektronicznych urn, czyli urządzeń za pomocą których wyborca oddaje głos przez naciśnięcie przycisku, maszyna ten głos zalicza, a wyborca dostaje pokwitowanie. W Polsce nie ma urn, które skanują karty do głosowania - wyborca wkłada kartę do głosowania w otwór urny, urna skanuje tę kartę, a wyborca otrzymuje potwierdzenie oddania głosu"19.

19 W Polsce długo nie będzie elektronicznych urn. Głosy licza ludzie, http://www. rmf24.pl/raporty/raport-wybory-prezydenckie2015/najnowsze-fakty/news-w-polsce- 
Ponadto, mając na względzie doświadczenia innych państw ${ }^{20}$ oraz nastawienie polskich obywateli do wykorzystania technologicznych nowinek $\mathrm{w}$ różnych dziedzinach życia ${ }^{21}$, wątpię $\mathrm{w}$ znaczenie technologii w procesie wyborczym i ich realny wpływ na frekwencję wyborczą. Oczywiście wraz $\mathrm{z}$ upływem czasu, popularyzacją technologii informatycznych, ewolucją w podejściu nie tylko do samego pomysłu zastosowania, ale i do obywatelskiego uczestnictwa w życiu publicznym, elektroniczne głosowanie w Polsce może stać się jak najbardziej realne i uzasadnione. Jest to jednak proces długotrwały, wymagający podjęcia różnorodnych działań, a przede wszystkim generujący duże koszty. Wbrew pozorom informatyczne rozwiązania w przypadku e-głosowania wiążą się z wydatkowaniem dużych środków finansowych (w szczególności w procesie oddawania głosu) ${ }^{22}$, zatem dopiero faktyczne zainteresowanie ze strony wyborców tą formą głosowania może uzasadnić ich zastosowanie w Polsce w całym procesie wyborczym.

\subsection{E-konsultacje społeczne}

Konsultacje społeczne to taka forma partycypacji obywatelskiej, która pozwala na uzyskiwanie opinii, poglądów, propozycji jednostek i tworzonych przez nie społeczności, przede wszystkim w tych sprawach, które w jakimś stopniu, bezpośrednio lub pośrednio, będą ich dotyczyć. „Konsultacje są (...) wymianą informacji z opinią publiczną, dyskusją, dzieleniem się wiedzą, a do pewnego stopnia nawet władzą. Dla podmiotów społecznych konsultacja stwarza możliwość uzyskania wpływu na treść rozwiązań, a dla administracji szereg możliwości ulepszenia jej działań. Konsultacje

-dlugo-nie-bedzie-elektronicznych-urn-glosy-licza-lu,nId,1731147\#utm_source=paste\&utm_medium =paste\&utm_campaign=chromehttp://www.rmf24.pl/raport-wybory-prezydenckie2015/najnowsze-fakty/news-w-polsce-dlugo-nie-bedzie-elektronicznych-urn-glosy-licza-lu,nId,1731147\#utm_source=paste\&utm_medium=paste\&utm_ campaign=firefox (dostęp: 3.02.2017).

20 Jak pisze M. Kowalski, „w wyborach samorządowych w Estonii w 2005 roku, pierwszych w tym kraju przeprowadzonych $\mathrm{z}$ wykorzystaniem również łącz internetowych, zaledwie $1,84 \%$ głosów oddano online. Ogólna frekwencja wyniosła w estońskich wyborach $47 \%$ (jak widać problem »tylko połowa głosuje «nie jest wyłącznie polską specyfiką), co tym samym oznacza, że mimo ogromnego poparcia dla technologii (85\% obywateli), skorzystało z niej faktycznie mniej niż jeden procent, a łączna frekwencja jak była niska, taka pozostała", M. Kowalski, Głosowanie przez Internet...

21 Zob. np. wyniki raportu Głównego Urzędu Statystycznego Społeczeństwo informacyjne w Polsce w 2014 r., http://stat.gov.pl/obszary-tematyczne/nauka-i-technika-spoleczenstwo-informacyjne/spoleczenstwo-informacyjne/spoleczenstwo-informacyjne-w-polsce-w-2014-r-,2,4.html (dostęp: 3.02.2017).

22 Przykładowo rząd Irlandii w 2004 r. kupił za ok. 50 mln euro od holenderskiej firmy Nedap specjalistyczny sprzęt wykorzystany jedynie w niektórych okręgach wyborczych, M. Kowalski, Głosowanie przez Internet... 
ze społeczeństwem są zatem jednym z najistotniejszych środków osiągania celów w polityce" 23 .

Przykłady z praktyki administracyjnej pozwalają stwierdzić, iż zastosowanie technologii informatycznych i telekomunikacyjnych w procesie konsultacji społecznych jest o wiele częściej spotykane i przy wykorzystaniu bardziej różnorodnych rozwiązań niż w przypadku głosowania. Stosowanie tych technologii rodzi również zazwyczaj mniej kontrowersji i problemów. W porównaniu ze sformalizowanymi, przebiegającymi według określonej procedury i zazwyczaj szczegółowo uregulowanymi w przepisach ordynacji wyborczych wyborami i referendami konsultacje społeczne zazwyczaj cieszą się mniejszym zainteresowaniem ze strony prawodawcy. Przepisy prawa w sposób ogólnikowy przewidują możliwość czy też obowiązek przeprowadzenia konsultacji społecznych w jakiejś określonej kategorii spraw, natomiast nie regulują już dokładnie ich przebiegu, organizacji, a tym bardziej formy, w jakiej mogą czy powinny zostać przeprowadzone. Zatem decyzja o tym, w jaki sposób i z zachowaniem jakich warunków zostaną przeprowadzane konsultacje społeczne, w dużej mierze zależy od podmiotów, które je organizują, np. od organów władz publicznych ${ }^{24}$. Decyzja organizatora może zatem dotyczyć również zastosowania rozwiązań nowoczesnych technologii w procesie konsultacji.

Do narzędzi często stosowanych w procesie konsultacji społecznych należą m.in.:

1) e-mail (poczta elektroniczna, list elektroniczny) - rozwiązanie najbardziej rozpowszechnione, najtańsze i często najefektywniejsze w zastosowaniu. Wyrażenie swojej opinii przez uczestnika konsultacji jest w tym przypadku uniezależnione od jego miejsca pobytu, a do skorzystania z niego wystarcza użycie jednego z wielu, często bezpłatnych programów pocztowych. Pewną zmodyfikowaną postacią komunikacji e-mailowej jest stworzenie tzw. elektronicznej listy mailingowej, tj. wspólnego adresu pocztowego. Zaletą tego rozwiązania jest szybkie i łatwe rozpowszechniane informacji i opinii zawartych w liście elektronicznym wśród uczestników dyskusji, ponieważ jego wysłanie we wskazany powyżej sposób sprawia, że trafia on do wielu uczestników;

2) fora internetowe (tzw. e-grupy) - to bardziej zaawansowana forma wymiany opinii czy stanowisk. Fora internetowe mogą mieć zróżnicowany charakter, od zaadresowanych do wszystkich zainteresowanych jakimś wątkiem, po fora skierowane wyłącznie do zaproszonych uczestników lub takich, których obecność i udział został zaakceptowany przez gospodarza grupy, mogą mieć charakter prywatny lub powszechny, pu-

23 D. Długosz, J.J. Wygnański, Obywatele współdecydują. Przewodnik po partycypacji społecznej, Warszawa 2005, s. 23.

24 Szerzej na temat standardów dotyczących organizacji i przeprowadzania konsultacji społecznych jest mowa m.in. w: D. Długosz, J.J. Wygnański, Obywatele wspótdecydują..., s. 23-45. 
bliczny. Wymiana opinii, stanowisk i informacji następuje przy pomocy elektronicznego formularza. Ten sposób komunikowania się daje możliwość bieżącego śledzenia wątków, jak również wymiany dokumentów, plików czy innych materiałów pomiędzy uczestnikami;

3) serwisy społecznościowe, jak np. Facebook czy Twitter, umożliwiające darmowe wysyłanie komentarzy czy krótkich wiadomości, które mogą być odczytywane przez inne osoby śledzące dany profil. Dają one możliwość nawiązania dyskusji poprzez odpowiadanie innym użytkownikom. Zaletą tego rozwiązania jest - choćby w związku z niezwykle intensywnym rozwojem technologii komunikacyjnych - możliwość wymiany opinii, stanowisk i informacji nie tylko poprzez wysyłanie ich ze swojego profilu przez stronę WWW, ale również SMS-em lub przez aplikacje mobilne, działające naurządzeniach przenośnych, takich jak telefony komórkowe, smartfony, palmtopy czy tablety, które pisane są przy użyciu różnych platform i języków programowania. Tym samym stwarza to możliwość konsultowania bez względu na miejsce położenia uczestnika dyskusji i znajdujące się w jego posiadaniu oprogramowanie;

4) komunikatory internetowe - to programy komputerowe pozwalające na przesyłanie natychmiastowych komunikatów pomiędzy dwoma lub większą liczbą komputerów, poprzez sieć komputerową, zazwyczaj Internet. To narzędzie pozwala na wymianę informacji, która przypomina prowadzenie bezpośredniej konwersacji. Komunikatory przesyłają informacje według reguł wynikających z protokołów komunikacyjnych w taki sposób, że publicznie udokumentowane protokoły są zwykle implementowane przez wiele komunikatorów, zapewniając prawie nieograniczone grono odbiorców. Ich zaletą jest również brak opłat za prowadzenie rozmów - „bez względu na to, czy są to rozmowy tekstowe, głosowe, czy wideorozmowy”25. Najczęściej wykorzystywane ze względu na opisane wyżej zalety komunikatory to Skype, Facebook Messenger itd.;

5) sondaże online - to narzędzie służące do zbierania opinii, stanowisk, informacji przy pomocy Internetu, w szczególności przy użyciu stron internetowych. Pozwala ono na przeprowadzenie swego rodzaju badań statystycznych, które mają na celu określenie preferencji poszczególnych grup społecznych. To narzędzie nie daje zazwyczaj pełnego, a jedynie przybliżony obraz poglądów na określony temat. Stanowi natomiast niewątpliwy dowód na pojawienie się pewnych trendów. Sondaże internetowe często stanowią jeden $\mathrm{z}$ wielu elementów składowych już istniejących stron internetowych lub też są głównym ich przedmiotem - przykładowo SONDA.pl jest to bezpłatne, szybkie i łatwe w użyciu narzędzie do budowy interaktywnych sondaży i ankiet, które umożliwia

25 D. Socha, 10 najlepszych darmowych komunikatorów internetowych, http:// www.benchmark.pl/testy_i_recenzje/najlepsze-darmowe-komunikatory-internetowe. html (dostęp: 4.02.2017). 
użytkownikom ocenianie, głosowanie i wyrażanie opinii ${ }^{26}$. Podobne cechy ma strona e-wybory.eu ${ }^{27}$;

6) serwisy internetowe, tworzone i prowadzone przez władze, stanowiące swego rodzaju elektroniczne platformy konsultacji społecznych - przykłady z polskiej administracji wskazują na to, że wiele podmiotów należących do administracji publicznej posiada i wykorzystuje takie rozwiązania. W odróżnieniu od konsultacji prowadzonych w tradycyjnych formach, utworzenie i funkcjonowanie takich elektronicznych platform konsultacji społecznych nie jest działaniem doraźnym, lecz zazwyczaj projektem o charakterze ciągłym. Elektroniczne platformy, stanowiące jeden z mechanizmów wyrażania relacji między administracją (władzą) publiczną a obywatelami jako partnerami społecznymi, poprzez swoją stosunkowo łatwą dostępność, możliwość skorzystania w każdym czasie i właściwie przez każdego zainteresowanego daną sprawą, mogą stanowić ważny element $\mathrm{w}$ budowaniu i prowadzeniu dialogu społecznego, a tym samym w rozwoju społeczeństwa obywatelskiego. Aby zostać nawet biernym obserwatorem konsultacji prowadzonych za pomocą takiej platformy, nie trzeba dokonywać żadnych szczególnych czynności - właściwie wystarczy jedynie skorzystać z wyszukiwarki internetowej i odnaleźć interesujące nas informacje, które są publikowane na stronach WWW takich serwisów internetowych. Natomiast aby móc stać się aktywnym uczestnikiem e-konsultacji i użytkownikiem takiej platformy, należy zazwyczaj utworzyć konto, na podobnych zasadach, jak ma to miejsce w przypadku innych funkcjonujących serwisów internetowych. Przyszły użytkownik określa swoją nazwę, login i hasło, a następnie wysyła te dane drogą internetową do administratora serwisu. $Z$ kolei na podany przez użytkownika adres e-mail zostaje wysłany link do strony serwisu w celu potwierdzenia rejestracji nowego użytkownika. Aktywacja konta następuje po kliknięciu w przesłany link. Przykładem wyżej opisanego rozwiązania jest np. serwis Miejskiego Centrum Dialogu Urzędu Miasta Krakowa ${ }^{28}$, powstały w 2008 r. i służący nie tylko przekazywaniu informacji na temat prowadzonych konsultacji społecznych, ale również pozwalający na przeprowadzanie internetowych konsultacji, czy serwis Konsultacje Społeczne Miasta Stołecznego Warszawy ${ }^{29}$.

Wskazane przykłady konsultacji elektronicznych stanowią najczęściej spotykane i wykorzystywane przez administrację publiczną sposoby na zasięganie opinii mieszkańców w odniesieniu do projektowanych przedsięwzięć i spraw publicznych. Czy e-konsultacje społeczne cieszą się w Polsce powodzeniem? Analizując materiały dotyczące konsultacji społecznych

26 Zob. http://www.sonda.pl/ (dostęp: 4.02.2017).

27 Zob. http://ewybory.eu/ (dostęp: 4.02.2017).

28 Zob. http://www.dialogspoleczny.krakow.pl (dostęp: 4.02.2017).

29 Zob. http://konsultacje.um.warszawa.pl (dostęp: 4.02.2017). 
przeprowadzanych na obszarze Gminy Miejskiej Kraków w sprawie m.in. przedsięwzięć inwestycyjnych, można było zauważyć, że e-konsultacje przez zainteresowanych sprawą mieszkańców były traktowane raczej jako jeden $z$ wielu sposobów na wyrażenie swojego stanowiska. Przeglądając i analizując materiały ze zgłoszonych drogą internetową postulatów, ze spotkań mieszkańców z przedstawicielami lokalnych władz itd., można dojść do wniosku, że tradycyjne metody przeprowadzania konsultacji cieszą się podobnie dużą popularnością i zainteresowaniem jak formy z wykorzystaniem nowoczesnych technologii. Wydaje się, że bezpośredni kontakt z przedstawicielami władz, możliwość bezpośredniej interakcji (na zasadzie: dzisiaj pytanie - dzisiaj odpowiedź) są dla wielu obywateli zainteresowanych daną sprawą równie cenne, a może nawet cenniejsze niż możliwość przesłania drogą elektroniczną opinii w sprawie publicznej w każdym czasie, o każdej porze, z każdego miejsca, gdzie się znajdują. Bezpośredni kontakt z przedstawicielami władz dla niektórych obywateli, w szczególności reprezentujących sceptyczne podejście do informatycznych i telekomunikacyjnych rozwiązań, traktowany jest często jako gwarancja, że ich zdanie w konkretnej sprawie nie zostanie pominięte i dotrze z pewnością do wiadomości władz.

Przykłady stosowania elektronicznych konsultacji zaczerpnięte z praktyki administracyjnej pokazują również, że wykorzystanie nowoczesnych technologii w przypadku tej formy partycypacji obywatelskiej wcale nie gwarantuje zwiększenia zainteresowania ze strony jednostek, obywateli sprawami publicznymi. Śledząc w szczególności wykorzystanie takich narzędzi jak choćby samorządowe serwisy internetowe oraz prowadzone za ich pomocą e-konsultacje, można zauważyć, że biernych ${ }^{30}$, a tym bardziej aktywnych ${ }^{31}$ użytkowników takich rozwiązań nie jest zbyt wielu ${ }^{32}$. Trudno jest znaleźć przyczynę tego stanu rzeczy. Z badań prowadzonych w zakresie zastosowania rozwiązań elektronicznej demokracji na poziomie samorządu terytorialnego i jego administracji wynika, że pomimo nakładów finansowych, w tym ze środków z budżetu Unii Europejskiej, e-administracja na tym poziomie nadal znajduje się dopiero na początku drogi ${ }^{33}$. W małych gminach nowoczesne technologie ograniczają się zazwyczaj jedynie do prowadzenia strony Biuletynu Informacji Publicznej (BIP) i ewentualnie urzędowej witryny internetowej, przy czym zawartość obu tych serwisów,

30 To jest jedynie śledzących informacje zamieszczane na stronach danego serwisu.

31 To jest wyrażających swoje opinie w danej sprawie, zgłaszających postulaty.

32 Przykładowo krakowski serwis internetowy www.dialoguj.pl miał na dzień 14 marca 2017 r. zarejestrowanych tylko 1980 użytkowników (biorąc pod uwagę zameldowanych mieszkańców Krakowa, których jest ok. 760 tys., jest to niewielka liczba), którzy dotychczas napisali w różnego rodzajach sprawach tylko 906 wiadomości.

33 T. Gajowniczek, Demokracja elektroniczna na przykładzie gmin powiatu olsztyńskiego [w:] Demokracja elektroniczna. Kontrowersje i dylematy, M. Marczewska-Rytko (red.), Lublin 2013, s. 303-314. 
ich przejrzystość i dostępność nadal pozostawia wiele do życzenia. Najczęściej też w mniejszych jednostkach samorządu terytorialnego nie stosuje się dodatkowych narzędzi, jak choćby wspomniane wyżej serwisy internetowe poświęcone konsultacjom społecznym. Takie rozwiązania są spotykane raczej w większych gminach, jak np. Kraków. Natomiast jeżeli już zostaną one zastosowane, to najczęściej w formie odrębnego od BIP-u serwisu internetowego. Być może mnożenie takich „internetowych” bytów utrudnia dotarcie do nich zainteresowanym, co poniekąd może wyjaśniać małe zainteresowanie ich wykorzystaniem.

Mając na uwadze powyższe dylematy, aby zachęcić obywateli do korzystania z elektronicznego systemu konsultacji, władze powinny podjąć działania wykraczające poza czynności techniczno-organizacyjne, polegające na zastosowaniu nowoczesnego rozwiązania, bowiem samo utworzenie platformy elektronicznych konsultacji czy zastosowanie innego narzędzia nie przesądzi o nagłym wzroście zainteresowania sprawami publicznymi ze strony obywateli. Jak pokazuje praktyka administracyjna, niezbędne jest podejmowanie przez władze, będące twórcami takich elektronicznych form konsultacji społecznych, również działań popularyzujących tego rodzaju rozwiązania i zachęcających obywateli do korzystania z nich. Propagowanie tej formy kontaktu obywateli z władzami i udziału w zajmowaniu się sprawami publicznymi powinno stać się integralnym elementem publicznej polityki informacyjnej.

\subsection{Informowanie z wykorzystaniem rozwiązań nowoczesnych technologii}

Działania informacyjne na linii obywatel - władza publiczna w dobie informatyzacji wielu dziedzin życia codziennego powinny zostać wzbogacone o zastosowanie rozwiązań informatycznych i telekomunikacyjnych. Tym bardziej że - jak zauważa się w piśmiennictwie - pozyskiwanie informacji jest jedną z najprostszych i najczęściej stosowanych form partycypacji, choćby ze względu na najmniejsze w porównaniu $\mathrm{z}$ innymi formami partycypacji zaangażowanie po stronie obywateli ${ }^{34}$. Zazwyczaj ta forma partycypacji polega na przekazywaniu informacji przez władzę publiczną (ma wówczas wymiar bierny) lub na pozyskiwaniu informacji od władz przez obywateli (forma udziału o charakterze czynnym). Informowanie zarówno w swoim wymiarze biernym, jak i czynnym jest często przedmiotem stosownych regulacji prawnych, które z różnym stopniem szczegółowości normują kwestie związane z udostępnianiem informacji o poszczególnych aspektach działalności władzy publicznej.

34 Zob. m.in. A. Olech, P. Sobiesiak-Peneszko, Partycypacja publiczna w Polsce. Diagnoza i rekomendacje, „Analizy i Opinie Instytutu Spraw Publicznych”, numer specjalny 3 , luty 2013, „Decydujmy razem”, s. 3. 
W polskim porządku prawnym do takich regulacji prawnych, oprócz przepisów Konstytucji RP z 1997 r. $^{35}$, należy przede wszystkim ustawa z dnia 6 września 2001 r. o dostępie do informacji publicznej ${ }^{36}$. Odnośnie do sposobów przekazywania i pozyskiwania informacji publicznej polski prawodawca założył różnorodność form, przy czym dokonując wykładni przepisów przywołanej regulacji, należy uznać, iż podstawowym sposobem przekazywania informacji stał się Biuletyn Informacji Publicznej oraz Centralne Repozytorium Informacji Publicznej, czyli rozwiązania bazujące na nowoczesnych technologiach. Świadczy o tym choćby przepis art. 10 ust. 1 ustawy o dostępie do informacji publicznej, stanowiący, iż udostępnianie na pisemny wniosek dotyczy przede wszystkim tych informacji publicznych, które nie zostały zamieszczone w Biuletynie Informacji Publicznej lub w centralnym repozytorium.

Biuletyn Informacji Publicznej to urzędowy publikator teleinformatyczny w postaci ujednoliconego systemu stron w sieci teleinformatycznej, powołany w celu powszechnego udostępniania informacji publicznej ${ }^{37}$. Natomiast centralne repozytorium to swego rodzaju baza danych, w ramach której gromadzi się i udostępnia informacje publiczne o szczególnym znaczeniu dla rozwoju innowacyjności w państwie i rozwoju społeczeństwa informacyjnego, które ze względu na sposób przechowywania i udostępniania pozwalają na ich ponowne wykorzystywanie w sposób użyteczny i efektywny ${ }^{38}$. Przewidziane przez prawodawcę rozwiązania, oparte na technologii informatycznej, mają stanowić podstawowy sposób przekazywania informacji o działalności władz publicznych.

Należy jednak zauważyć, że nie są to jedyne sposoby udostępniania informacji z wykorzystaniem technologii informatycznych, które przewiduje obowiązujące prawo. Warto wspomnieć także choćby określone w przepisach ustawy z dnia 14 czerwca 1960 r. - Kodeks postępowania administracyjnego ${ }^{39}$ przypadki dokonywania czynności procesowych, $\mathrm{w}$ tym polegających na przekazywaniu informacji, $w$ formie dokumentu elektronicznego uwierzytelnionego za pomocą mechanizmów określonych w ustawie $\mathrm{z}$ dnia 17 lutego 2005 r. o informatyzacji działalności podmiotów realizujących zadania publiczne ${ }^{40}$. Taką formę przewiduje się m.in. przy udzieleniu pełnomocnictwa procesowego, doręczeniach pism i dokumentów w postępowaniu, składaniu podań, wniosków i innych pism przez uczestników postępowania, przeglądaniu akt sprawy, sporządzaniu z nich notatek, kopii lub odpisów, wydaniu decyzji, zaświadczeń itd. Ponadto zastosowanie nowoczesnych technologii przy pozyskiwaniu i udostępnianiu informacji prze-

35 W szczególności art. 61 Konstytucji (Dz. U. Nr 78, poz. 483 ze zm.).

36 Tekst jednolity Dz. U. z 2016 r. poz. 1764 ze zm.

37 Art. 8 ust. 1 ustawy o dostępie do informacji publicznej.

38 Art. 9a ust. 1 ustawy o dostępie do informacji publicznej.

39 Tekst jedn.: Dz. U. z 2016 r. poz. 23 ze zm.

40 Tekst jedn.: Dz. U. z 2017 r. poz. 570 ze zm. 
widują liczne regulacje materialnego prawa administracyjnego, szczegółowo normujące niektóre formy obywatelskiej partycypacji, jak np. ustawa $z$ dnia 3 października 2008 r. o udostępnianiu informacji o środowisku i jego ochronie, udziale społeczeństwa w ochronie środowiska oraz o ocenach oddziaływania na środowisko ${ }^{41}$.Zakłada ona m.in. udostępnianie informacji o środowisku i jego ochronie za pośrednictwem systemów teleinformatycznych, w szczególności przy wykorzystaniu elektronicznych baz danych ${ }^{42}$.

\section{3. „Informatyzacja” uczestnictwa obywateli w sprawach publicznych i jej znaczenie dla rozwoju społeczeństwa obywatelskiego w Polsce}

Przedstawione $\mathrm{w}$ niniejszym opracowaniu przykłady zastosowania do poszczególnych form partycypacji obywatelskiej nowoczesnych technologii pokazują, że mogą one bez wątpienia służyć ułatwieniu korzystania z partycypacji, co w założeniu twórców tych metod ma również przyczynić się do wzrostu zaangażowania obywateli w sprawy publiczne. Można bowiem przypuścić, że skoro technologie te sprawdzily się $\mathrm{w}$ wielu prywatnych sferach życia jednostki, jak np. edukacja, medycyna, ekspresja własnych poglądów czy twórczości, to równie dobrze mogą znaleźć zastosowanie przy realizacji przez jednostkę prawa udziału w życiu publicznym i w zajmowaniu się sprawami publicznymi. Wedle poglądów reprezentowanych w literaturze przez entuzjastów elektronicznej demokracji „to, co jeszcze kilka lat temu wydawało się fantazją, dziś staje się rzeczywistością. Rozwój technologii ma i będzie miał olbrzymie znaczenie dla sposobu funkcjonowania państwa i jego relacji z obywatelami. Tworzą się bowiem zupełnie nowe mechanizmy, zarówno w dziedzinie upowszechniania informacji, jak i konsultacji, a nawet współdecydowania (elektroniczne referenda)" ${ }^{\prime 3}$. Można zatem sądzić, że informatyzacja, podobnie jak inne dotychczas występujące czynniki (np. obowiązujące prawo, ustrój państwowy, czynniki natury politycznej, ekonomicznej itd.) może mieć znaczenie dla zwiększenia zaangażowania jednostek $\mathrm{w}$ sprawy publiczne.

W literaturze i w praktyce administracyjnej można spotkać zarówno zwolenników, jak przeciwników tej technologicznej modernizacji. Biorąc pod uwagę ich opinie, jak i doświadczenia, wśród najczęściej wymienianych zalet zastosowania nowoczesnych technologii wyróżnia się:

1) poszerzenie dostępności do informacji o sprawach publicznych i zwiększenie transparentności działania władz publicznych, w szczególności przejrzystości procesów decyzyjnych;

41 Tekst jedn.: Dz. U. z 2016 r. poz. 353 ze zm.

42 Art. 24 ust. 1 ustawy o udostępnianiu informacji o środowisku i jego ochronie, udziale społeczeństwa w ochronie środowiska oraz o ocenach oddziaływania na środowisko.

43 D. Długosz, J.J. Wygnański, Obywatele współdecydujq̨..., s. 46. 
2) aspekt ekonomiczny, charakteryzujący się niskimi kosztami wdrożenia tych technologii i ich stosowania ${ }^{44}$;

3) zmniejszenie liczby głosów nieważnych w przypadku głosowania w ramach wyborów czy referendum ${ }^{45}$;

4) ułatwienie administracji publicznej organizacji i przeprowadzenia głosowania, konsultacji społecznych czy prowadzenia polityki informacyjnej;

5) zwiększenie szybkości procesów demokratycznych, począwszy od współdecydowania poprzez konsultacje, a skończywszy na pozyskiwaniu informacji;

6) zwiększenie interaktywności pomiędzy uczestnikami procesów demokratycznych - przyspieszenie i ułatwienie procesów komunikacji i wzajemnego oddziaływania na siebie ich uczestników;

7) zagwarantowanie na bieżąco aktualnej informacji i wiedzy na temat spraw publicznych;

8) zmianę postrzegania konkretnych polityków czy ugrupowań politycznych, w szczególności tych promujących elektroniczne formy partycypacji obywatelskiej ${ }^{46}$;

9) urzeczywistnienie w sieci zasady równości jako jednej z fundamentalnych zasad demokracji ${ }^{47}$;

10) zwiększenie zainteresowania udziałem w procesach demokratycznych i stosowanymi w ich ramach formami partycypacji obywatelskiej, szczególnie wśród młodych ludzi ${ }^{48}$;

11) zapewnienie warunków uczestnictwa w sprawach publicznych tym osobom, które z powodu takich przeszkód, jak, np. niepełnosprawność, choroba, przebywanie poza siedzibą właściwego lokalu wyborczego, nie mogły dotychczas w tych formach demokracji uczestniczyć. Nie jest to oczywiście zamknięty katalog pozytywnych stron wykorzystania w partycypacji obywatelskiej nowoczesnych technologii, mogących przyczynić się do rozwoju społecznego zainteresowania sprawami publicznymi. Sądzę, że przy każdej z opisanych wcześniej form społecznego i obywatel-

44 Ibidem.

45 Według M. Kowalskiego „przy właściwym wdrożeniu takiego systemu, każdy oddany przez obywatela głos będzie głosem ważnym. Na papierowym arkuszu wyborczym wyborca może teoretycznie napisać cokolwiek, popełnić błąd (nie ma znaczenia czy umyślny, czy też nie) i tym samym oddać nieprawidłowy głos. W przypadku systemu elektronicznego tego typu błędy można wyeliminować, Głosowanie przez Internet...

46 M. Musiał-Karg, Elektroniczne głosowanie. Wybrane dylematy dotyczace e-votingu [w:] Demokracja elektroniczna..., s. 87.

47 Ibidem.

48 Zob. na ten temat również E. Bendyk, Niezapowiedziane rewolucje, „Polityka” 2004, nr 27, dodatek „Niezbędnik Inteligenta”; M. Marczewska-Rytko, Demokracja bezpośrednia w teorii i praktyce politycznej, Lublin 2001. 
skiego zaangażowania w sprawy publiczne można byłoby wskazać również inne zalety, ściśle związane z daną formą.

Jednakże dla zaprezentowania pełnego obrazu tego zagadnienia należy zwrócić uwagę także na wady i ograniczenia związane z użyciem technologii informatycznych w procesach demokratycznych. W odpowiedzi bowiem na twierdzenia zwolenników zastosowania nowoczesnych technologii, iż pozwalają one na zwiększenie poziomu partycypacji, przeciwnicy odpowiadają, że nie można tego uznać za pewnik. Efekt ten w dużej mierze zależy od warunków panujących w danej społeczności oraz od postawy prezentowanej przez jej członków. Można bowiem w doświadczeniach związanych z zastosowaniem nowych technologii znaleźć przypadki, kiedy ich wprowadzenie kilkakrotnie zwiększyło udział obywateli w tych procesach demokratycznych ${ }^{49}$, jak również takie, gdy rzeczywiście doszło do wzrostu zaangażowania obywateli w sprawy publiczne, ale zmiany te następowały bardzo powoli, niejako małymi krokami, a kilkuprocentowy czy nawet kilkunastoprocentowy wzrost zaangażowania w wybory, referendum czy inne formy partycypacji trudno w takiej sytuacji przypisać w sposób jednoznaczny zastosowaniu nowoczesnych technologii ${ }^{50}$.

Najwięcej negatywnych stron zastosowania technologii informatycznych dostrzega się przy tych formach partycypacji, których istota polega na decydowaniu bądź współdecydowaniu o sprawach publicznych, np. w przypadku wyborów czy referendum ${ }^{51}$. Zwraca się uwagę na takie negatywne aspekty, jak:

1) zagrożenie tajności głosowania;

49 Przykładowo wykorzystanie Internetu w prawyborach Partii Demokratycznej w stanie Arizona spowodowało, że wzięło w nich udział sześciokrotnie więcej obywateli niż w przypadku zastosowania tradycyjnych metod, R. Lawson Mack, The digital divide: standing at the intersection of race and technology, Durham 2001, s. 143, za: P. Maj, Reprezentacja, partycypacja i transparentność systemu - zmiany w rozumieniu zasad demokracji w kontekście funkcjonowania sieci globalnej, „Annales Universiatis Mariae Curie-Skłodowska”, Lublin 2009, vol. XVI, no. 1, s. 167.

50 Do takich wniosków może prowadzić przykład Estonii - pioniera w stosowaniu technologii informatycznych w procesach partycypacyjnych. Podczas wyborów lokalnych w Tallinie w2005 r. tę formę głosowania wybrało 1,84\% wyborców. W wyborach parlamentarnych w 2007 r. elektronicznie zagłosowało 5,5\% wyborców, w wyborach do Parlamentu Europejskiego w 2007 r. przez Internet oddano 14,7\% głosów, a w 2011 r. w wyborach parlamentarnych $-24,3 \%$ wyborców wybrało drogę internetowego głosowania. Zob. na ten temat: Czy e-głosowanie pomoże zwiększyć wyborcza frekwencję?, http://www.europarl.europa.eu/news/pl/news-room/content/20110321STO15986/ html/Czy-eg\%C5\%82osowanie-pomo\%C5\% BCe-zwi\%C4\%99kszy\%C4\%87-wyborcz\%C4\%85-frekwencj\%C4\%99 (dostęp: 10.02.2017).

51 Zob. na temat niebezpieczeństw związanych z elektronicznym głosowaniem: A. Kukwa, E-wybory? Bezpieczeństwo głosów w wyborach elektronicznych wciąż zawodne, http://www.spidersweb.pl/2012/11/e-wybory-bezpieczenstwo-glosow-wyborach-elektronicznych-wciaz-zawodne.html (dostęp: 10.02.2017); D. Długosz, J.J. Wygnański, Obywatele współdecydują..., s. 46. 
2) zmniejszenie przejrzystości samego procesu głosowania (brak możliwości śledzenia procesu głosowania, liczenia głosów itd.);

3) ryzyko powstania zakłóceń technicznych podczas głosowania, które mogą nie tylko utrudnić sam jego przebieg, ale również wpłynąć na wynik głosowania;

4) trudności w zidentyfikowaniu wyborcy;

5) ryzyko naruszenia ciszy wyborczej;

6) ryzyko podejmowania decyzji wyborczych impulsywnie, bez głębszego zastanowienia;

7) zagrożenie sprzedawaniem głosów.

Ponadto zwraca się uwagę na takie bariery elektronicznej demokracji, jak:

1) zjawisko nierównego dostępu do Internetu(tzw. digital divide, digital split, e-excliusion), czyli występującego na różnych poziomach „cyfrowego podziału”, „cyfrowej przepaści” czy też elektronicznego wykluczenia ${ }^{52}$;

2) brak zainteresowania taką formą partycypacji ze strony obywateli mniej wykształconych, starszych, o mniejszych dochodach ${ }^{53}$;

3) wysokie koszty wdrożenia rozwiązań technologicznych, które de facto - ze względu na kadencyjność organów, do których przeprowadza się wybory - będą miały sporadyczne zastosowanie;

4) brak powszechnych wśród członków danej społeczności umiejętności korzystania z nowoczesnych technologii (kompetencji) itd.

Przedstawione powyżej obawy i dylematy nie są oczywiście bez znaczenia. Jednakże należy zaznaczyć, że ryzyko powstania zagrożeń dla prawidłowego przebiegu np. głosowania można pojawić się również wtedy, gdy wybory czy referendum jest prowadzone w konwencjonalnej formie. Jak można zauważyć, obawy związane z zastosowaniem rozwiązań elektronicznej demokracji zdecydowanie rzadziej spotyka się przy innych formach partycypacji, które charakteryzuje mniejszy stopień społecznego zaangażowania. Jak to zostało wcześniej zaprezentowane, coraz częściej można spotkać zastosowanie rozwiązań informatycznych przy szeroko pojętych konsultacjach społecznych. Natomiast w zakresie pozyskiwania informacji publicznych można nawet zaobserwować tendencję do traktowania informowania drogą internetową jako jednej z podstawowych form realizacji prawa dostępu do informacji. Biorąc pod uwagę naturalne różnice pomiędzy poszczególnymi formami obywatelskiego uczestnictwa w sprawy publiczne, należy moim zdaniem w procesie ich technologicznej modernizacji każdą z nich traktować w sposób odrębny, szczególny. Rodzaj i stopień wykorzystania nowoczesnych technologii powinien być bowiem dostosowany odpowiednio do charakteru danej formy partycypacji obywatelskiej.

52 Szerzej na ten temat, m.in. P. Norris, Digital divide. Civic engagement, information poverty, and the Internet worldwide, Cambridge 2001.

53 Na przykładzie prawyborów w Arizonie z 2000 r. zob. M. Musiał-Karg, Elektroniczne głosowanie..., s. 90. 
Mając na uwadze wymienione przykładowo w niniejszym opracowaniu zagrożenia związane $\mathrm{z}$ wdrożeniem nowoczesnych technologii przy stosowaniu poszczególnych form partycypacji obywatelskiej, uważam, że w tym zakresie trzeba być ostrożnym. Podjęcie decyzji o zastosowaniu rozwiązań informatycznych, w szczególności w procesie oddawania głosu, powinno zostać poprzedzone szeregiem czynności przygotowawczych w ramach tzw. programów pilotażowych ${ }^{54}$. Bez wątpienia zalety zastosowania tych technologii są niezwykle istotne dla idei społeczeństwa obywatelskiego, jednakże nie wolno zapominać o towarzyszących im zagrożeniach dla poprawności stosowania poszczególnych form partycypacji obywatelskiej, a nawet dla interesów państwa czy obywateli.

Przy podejmowaniu decyzji co do zastosowania takich technologii należy wziąć pod uwagę również to, w jaki sposób postrzegane są przez jednostki i tworzone przez nie społeczności poszczególne formy partycypacji realizowane w tradycyjny sposób. Niektórzy przedstawiciele nauki zarzucają współczesnej władzy, jej administracji, jak również samym obywatelom nie tylko słabe i rzadkie wykorzystanie form partycypacji, co ograniczanie się do wykorzystania przede wszystkim konwencjonalnych metod ich realizacji55. Sądzę jednak, iż stosowanie konwencjonalnych sposobów zapewnienia udziału obywateli w realizacji zadań publicznych należy nadal uznawać za ważne i cenne dla samych obywateli, władz czy procesów demokratycznych. Bowiem przez niektórych uczestników życia publicznego tradycyjne metody realizacji form partycypacji obywatelskiej mogą być „postrzegane jako pewnego rodzaju ceremonia”, zaś zastosowanie rozwiązań informatycznych, które tą cechę eliminuje, zostanie uznane za swego rodzaju trywializację i obniżenie rangi partycypacji obywatelskiej ${ }^{56}$.

Postawa złotego środka podpowiada zatem, że nie należy przeceniać znaczenia informatyzacji, tak samo zresztą jak nie wolno nie doceniać możliwości i zalet zastosowania nowoczesnych technologii w przypadku poszczególnych form partycypacji obywatelskiej. Uważam w związku z tym, że współcześnie z całą pewnością niemożliwe są do przyjęcia i realnego zastosowania - nie tylko w Polsce, ale również w innych państwach o ustroju demokratycznym - postulaty zwolenników tzw. netarchii, czyli koncepcji demokracji sieciowej, krytykujących tradycyjną demokrację przedstawicielską, jak i instytucje demokracji bezpośredniej i postulujących ich zastąpienie e-demokracją uczestniczącą, którzy stawiają znak równości pomiędzy światem realnym a wirtualnym ${ }^{57}$.

54 Ibidem.

55 Zob. A. Olech, P. Sobiesiak-Peneszko, Partycypacja publiczna w Polsce...

56 M. Sztelmach, Wybory przez Internet...

57 Zob. więcej na ten temat: A. Sikora, Koniec demokracji przedstawicielskiej, cz. A, http://progg.eu/?p=1252 (dostęp: 11.02.2017); D. Maj, Netarchia - koncepcja demokracji sieciowej [w:] Demokracja elektroniczna..., s. 293-302. 


\section{Podsumowanie}

Technologie informatyczne nie mogą zastąpić tradycyjnych metod udziału i zainteresowania ze strony obywateli sprawami publicznymi. Ich wykorzystywanie dla rozwoju społeczeństwa obywatelskiego może mieć $\mathrm{z}$ biegiem czasu coraz większe znaczenie i zastosowanie. W polskich realiach, jak pokazują przykłady z praktyki, będzie to jednak raczej-z różnych względów, o których była mowa wcześniej - proces powolny i rozłożony w czasie. Do takich wniosków prowadzą również wyniki raportu Głównego Urzędu Statystycznego Społeczeństwo informacyjne w Polsce w 2016 roku ${ }^{58}$, które wskazują na to, iż proces informatyzacji polskiego społeczeństwa $\mathrm{z}$ roku na rok charakteryzuje coraz większa dynamika i rosnące zapotrzebowanie na lepszą jakość usług i produktów ICT. Wprawdzie coraz więcej gospodarstw domowych posiada komputery czy inne urządzenia oparte na technologii informatycznej (w 2016 r. 80,1\% gospodarstw domowych miało już w domu przynajmniej jeden komputer), wiele z nich posiada dostęp do Internetu (dostęp do Internetu w 2016 r. posiadało 80,4\% gospodarstw domowych, w tym $75,7 \%$ - szerokopasmowy), jednakże jak wynika z przeprowadzonych badań, nadal jest spora grupa obywateli nieposiadających dostępu do Internetu w domu, najczęściej wskazujących na takie przyczyny, jak brak potrzeby korzystania z sieci (70,6 \%), brak odpowiednich umiejętności $(52,1 \%)$, zbyt wysokie koszty sprzętu (28\%) czy dostępu do Internetu $(21,3 \%)$. Inne wymieniane powody to: niechęć do Internetu (9,9\%), względy prywatności lub bezpieczeństwa $(3,9 \%)$, brak technicznych możliwości korzystania i podłączenia do Internetu $(0,8 \%)$.

Dlatego też z tych, jak i innych wcześniej zaprezentowanych powodów obecnie zastosowanie rozwiązań nowoczesnych technologii należy traktować raczej jako kolejny, niezwykle przydatny, ale jak na razie subsydiarny model działania ułatwiający i uzupełniający partycypację obywatelską $\mathrm{w}$ tradycyjnej postaci.

\section{Bibliografia}

Bendyk E., Niezapowiedziane rewolucje, „Polityka” 2004, nr 27, dodatek „Niezbędnik Inteligenta".

Bennett W.I., Entman R.M., Mediated politics: communication on the future of democracy, Cambrigde-New York 2005.

Czakowski M., Evotingna przykładzie Estonii i Brazylii, „Studia BAS” 2011, nr 3 (27).

Czy e-głosowanie pomoże zwiększyć wyborcza frekwencję?, http://www.europarl. europa.eu/news/pl/news-room/content/20110321STO15986/html/Czy-e

58 GUS, Społeczeństwo informacyjne w Polsce w 2016 roku, http://stat.gov.pl/ obszary-tematyczne/nauka-i-technika-spoleczenstwo-informacyjne/spoleczenstwo-informacyjne/spoleczenstwo-informacyjne-w-polsce-w-2016-roku,2,6.html (dostęp: 11.02.2017). 
g\%C5\%82osowanie-pomo\%C5\%BCe-zwi\%C4\%99kszy\%C4\%87-wyborcz\%C4\%85-frekwencj\%C4\%99.

Długosz D., Wygnański J.J., Obywatele współdecydują. Przewodnik po partycypacji społecznej, Warszawa 2005.

Gajowniczek T., Demokracja elektroniczna na przykładzie gmin powiatu olsztyńskiego [w:] Demokracja elektroniczna. Kontrowersje i dylematy, M. Marczewska-Rytko (red.), Lublin 2013.

GUS, Społeczeństwo informacyjne w Polsce w 2014 roku, http://stat.gov.pl/obszarytematyczne/nauka-i-technika-spoleczenstwo-informacyjne/spoleczenstwo-informacyjne/spoleczenstwo-informacyjne-w-polsce-w-2014-r-,2,4.html.

Hess A., Społeczni uczestnicy medialnego dyskursu politycznego w Polsce. Mediatyzacja i strategie komunikacyjne organizacji pozarządowych, Kraków 2013.

Komunikacja i partycypacja społeczna. Nowoczesna Gmina - jak wykorzystać komunikacje i partycypacje społeczna jako skuteczne narzędzia zarzadzania jednostka samorzadowa, http://www.cds.krakow.pl/komunikacja_i_partycypacja_spoleczna, $125 . h t m l$.

Koczubiej S., E-głosowanie jako element demokracji w społeczeństwie informacyjnym, „Problemy Humanistyki” 2003/2004, nr 8/9.

Kowalski M., Głosowanie przez internet - dlaczego jeszcze nie w Polsce? Korzyści i zagrożenia związane $z$ wyborami elektronicznymi, http://softonet.pl/publikacje/poradniki/Glosowanie.przez.internet-dlaczego.jeszcze.nie.w.Polsce.Korzysci.i.zagrozenia.zwiazane.z.wyborami.elektronicznymi,1383.

Kukwa A., E-wybory? Bezpieczeństwo głosów w wyborach elektronicznych wciąż zawodne, http://www.spidersweb.pl/2012/11/e-wybory-bezpieczenstwo-glosow-wyborach-elektronicznych-wciaz-zawodne.html.

Lawson Mack R., The Digital divide: standing at the intersection of race and techno$\log y$, Durham 2001.

Maj D., Netarchia - koncepcja demokracji sieciowej [w:] Demokracja elektroniczna. Kontrowersje i dylematy, M. Marczewska-Rytko (red.), Lublin 2013.

Maj P., Reprezentacja, partycypacja i transparentność systemu - zmiany w rozumieniu zasad demokracji w kontekście funkcjonowania sieci globalnej, „Annales Universiatis Mariae Curie-Skłodowska”, Lublin 2009, vol. XVI, nr 1.

Marczewska-Rytko M., Demokracja bezpośrednia w teorii i praktyce politycznej, Lublin 2001.

Marczewska-Rytko M., Demokracja elektroniczna jako próba urzeczywistnienia idei greckiej agory [w:] Społeczeństwo informacyjne: wizja czy rzeczywistość?, t. 2, L.H. Haber (red.), Kraków 2004.

Musiał-Karg M., Demokracja bezpośrednia w Szwajcarii. Wykorzystanie ICT w procedurach głosowania [w:] Demokracja bezpośrednia. Wymiar globalny i lokalny, M. Marczewska-Rytko, A.K. Piasecki (red.), Lublin 2010.

Nodżak A., Obywatelskie prawo inicjatywy uchwałodawczej [w:] Legislacja czasu przemian, przemiany w legislacji. Księga jubileuszowa na XX-lecie Polskiego Towarzystwa Legislacji, M. Kłodawski, A. Witorska, M. Lachowski (red.), Warszawa 2016.

Norris P., Digital divide. Civic engagement, information poverty, and the Internet worldwide, Cambridge 2001. 
Olech A., Sobiesiak-Peneszko P., Partycypacja publiczna w Polsce. Diagnoza i rekomendacje, „Analizy i Opinie Instytutu Spraw Publicznych”, numer specjalny 3, luty 2013, „Decydujmy razem”.

Sikora A., Koniec demokracji przedstawicielskiej, cz. A, http://progg.eu/?p=1252.

Socha D., 10 najlepszych darmowych komunikatorów internetowych, http://www. benchmark.pl/testy_i_recenzje/najlepsze-darmowe-komunikatory-internetowe.html.

Sztelmach M., Wybory przez Internet - szansa czy zagrożenie?, http://www.psl.garwolin.pl/index.php/e-wybory-szansa-czy-zagroenie.

Tarasewicz A., E-demokracja, czyli nowe technologie w polityce, http://educover.pl/ czasopismo/e-demokracja-nowe-technologie-polityce/2/.

W Polsce dtugo nie będzie elektronicznych urn. Głosy licza ludzie, http://www.rmf24. pl/raport-wybory-prezydenckie2015/najnowsze-fakty/news-w-polsce-dlugonie-bedzie-elektronicznych-urn-glosy-licza-lu,nId,1731147\#utm_source=paste\&utm_medium=paste\&utm_campaign=firefox.

Wróbel I., Szwajcarskie doświadczenia w głosowaniu przez Internet na przykładzie kantonu Zurych - wnioski dla Polski, ,e-Biuletyn Centrum Badań Problemów Prawnych i Ekonomicznych Komunikacji Elektronicznej” 2008, nr 3, http:// www.bibliotekacyfrowa.pl/dlibra/docmetadata?id=34345\&from $=\&$ dirid$\mathrm{s}=1 \& \mathrm{ver}$ id=\&lp=1\&QI=3D5E0A7FE21CDCC-B96474A99A7AFE220-2.

Zacher L.W., Etykietowanie przyszłych społeczeństw - kryteria, określenia, ewaluacje [w:] U progu wielkiej zmiany? Media w kulturze XXI wieku, M. Sokołowski (red.), Olsztyn 2005.

Żelazny R., Raport Obserwatorium ITC. Społeczeństwo informacyjne, Gliwice 2013.

Streszczenie

Postęp cywilizacyjny i towarzyszący mu rozwój nowoczesnych technologii wpłynął na wiele dziedzin życia, w tym dziedziny życia publicznego. Rozwój ten towarzyszy przemianom gospodarczym, a nawet politycznym czy społecznym. Jednym z przejawów przemian społecznych na skutek rozwoju nowoczesnych technologii jest wykształcenie się nowoczesnego społeczeństwa, określanego w literaturze jako społeczeństwo informacyjne, sieciowe, cyfrowe, telematyczne itd. W poszczególnych państwach, w tym również $\mathrm{w}$ Polsce, przewiduje się wdrożenie i stosowanie narzędzi opartych na osiągnięciach nowoczesnych technologii w różnych dziedzinach życia publicznego. Technologie te mają znaleźć powszechne zastosowanie w przypadku różnych form partycypacji obywatelskiej w życiu publicznym, takich jak wybory, referendum, konsultacje społeczne czy prawo do informacji publicznej. Autorka szuka odpowiedzi na pytania, czy zakładana informatyzacja poszczególnych form udziału obywateli w życiu publicznym zmieni ich charakter? Czy ułatwi obywatelom udział w życiu publicznym, zachęci ich do aktywnego uczestnictwa i tym samym zażegna tzw. kryzys demokracji? Czy zastosowanie technologii informatycznych i telekomunikacyjnych może mieć realny wpływ na rozwój społeczeństwa obywatelskiego?

Słowa kluczowe: partycypacja obywatelska, technologie informatyczne i telekomunikacyjne, elektroniczna demokracja 


\section{The Use of Modern Technology in the Context of Civil Society Development in Poland}

Abstract

The progress of civilisation and the simultaneous development of modern technology have affected many areas of life, including public life. This development is accompanied by economic changes and even political or social ones. One of the manifestations of social change as a result of the development of modern technology is the emergence of modern society, referred to in the literature of the subject as information, network, digital, telematic, etc. society. At the level of individual countries, including Poland, it is expected that tools will be implemented and applied based on the achievements of modern technologies in various areas of public life. Namely, the above-mentioned technologies have found widespread use in the case of various forms of civic participation in public life, such as elections, referenda, public consultations and the right to public information. Would the "computerisation" of various forms of citizens' participation in public life change their nature? Would it make it easier for citizens to participate in public life, encourage them to take an active part and thus quell the so-called crisis of democracy? Can the use of information and telecommunication technologies have a real impact on the development of civil society?

Keywords: civic participation, information and communication technologies, electronic democracy 